\title{
PERANAN KOMUNIKASI DALAM KEPEMIMPINAN PEMERINTAHAN DAN PARTISIPASI MASYARAKAT
}

\author{
Linda Christine S. Paembonan \\ lindasumilat@gmail.com
}

\begin{abstract}
The role of communication in the government's leadership in an attempt to influence, move, guide and direct its community or follower is a very important factor for the realization of the goals set. Government leaders as a mover and a good communicator will clarify perceptions and convince his followers to engage and active participate in the development activities; all at once as a proof that government is practicing the communitybased development or it is so called development from, by and for the people.
\end{abstract}

Keywords: Communication role, Government leadership, Community-based development.

\section{Pendahuluan}

Kepemimpinan merupakan faktor yang sangat menentukan dalam penyelenggaraan pemerintahan dan pembangunan. Dikatakan demikian karena arah strategi dan kebijakan di gerakkan oleh pemimpin untuk mencapai tujuan yaitu mewujudkan kesejahteraan rakyat melalui kegiatan pelayanan masyarakat, pemberdayaan masyarakat, pembangunan sumber daya alam dan sumber daya manusia, serta penataan regulasi.

Sebagaimana pelaksanaan kepemimpinan pada umumnya membutuhkan banyak faktor seperti kemampuan managerial, gaya kepemimpinan, ketajaman visi, kemampuan mengkoordinasikan dan menggerakan masyarakat, kecepatan mengambil keputusan serta kemampuan berkomunikasi baik secara internal maupun secara eksternal. Dalam kaitan ini akan disoroti secara khusus tentang aspek komunikasi sebagai salah satu unsur terpenting bagi keberhasilan seorang pemimpin di dalam menggerakan partisipasi masyarakat.

Pada dasarnya kemampuan berkomunikasi dalam perspektif kepemimpinan dan partisipasi masyarakat dimaksudkan sebagai upaya yang sadar, terarah dan terencana dalam menyampaikan pesan-pesan pembangunan dan pemerintahan yang wajib di ketahui secara jelas oleh masyarakat sehingga mereka dapat mengambil bagian sesuai dengan kemampuan dan situasi dimana peran serta dapat di lakukan.

Dalam proses komunikasi seperti ini membutuhkan pemahaman dan pengertian yang memungkinkan masyarakat dengan mudah dapat mengerti dan memahami arti terdalam dari pesan-pesan yang disampaikan pemimpinnya untuk 
mempengaruhi dan menggerakan masyarakat mengambil bagian dalam kegiatan pembangunan sebagai upaya menyatakan hak dan kewajibannya sebagai warga Negara yang baik dan bertanggung jawab.

Komunikasi yang sederhana dan persuasif akan memberi penyadaran secara lebih mudah dan akan lebih cepat mendapatkan respons dari masyarakat karena mereka telah menyadari dan mengerti bahwa pesan-pesan pembangunan yang disampaikan pemimpinnya kepada mereka merupakan sesuatu yang membawa manfaat bagi kepentingan dan perkembangan masyarakat.

\section{Pemimpin dan Kepemimpinan}

Fungsi kepemimpinan dalam penyelenggaraan pemerintahan sangat penting, karena fungsi kepemimpinan tidak hanya menonjolkan kepemimpinan sebagai pemimpin formal, tetapi juga bagaimana proses seseorang melaksanakan kepemimpinannya. Di masyarakat sering menimbulkan kerancuan antara kata pemimpin dengan kepemimpinan. Mereka sering memaknai bahwa keduanya memiliki arti yang sama antara pemimpin dengan kepemimpinan. Kalau ditinjau lebih jauh, sesungguhnya istilah pemimpin dan kepemimpinan tidak jauh berbeda dengan istilah pemerintah dan pemerintahan, dimana keduanya memiliki arti yang berbeda. Kalau pemerintah merupakan lembaga atau institusi negara sedangkan pemerintahan adalah proses kegiatan dari lembaga tersebut.

Demikian pula halnya dengan pemimpin dan kepemimpinan, dimana keduanya memiliki perbedaan makna sebagaimana halnya pemerintah dengan pemerintahan. Menurut Pasolong (2008 : 1), konsep kepemimpinan pada dasarnya berasal dari kata "pimpin" yang artinya bimbing atau tuntun. Dari kata "pimpin" melahirkan kata kerja "memimpin" yang artinya membimbing atau menuntun dan kata benda "pemimpin" yaitu orang yang berfungsi memimpin, atau orang yang membimbing atau menuntun. Sedangkan kepemimpinan yaitu kemampuan seseorang dalam mempengaruhi orang lain dalam mencapai tujuan.

Lebih jauh Wirawan (2002 : 65) mendefinisikan bahwa kepemimpinan terjadi jika ada pemimpin mempengaruhi pengikutnya. Hakekat yang terkandung dalam definisi tersebut penekanannya kepada nilai proses, dimana kepemimpinan terjadi jika ada pemimpin mempengaruhi pengikutnya. Pemimpin merupakan unsur esensial dari kepemimpinan, tanpa pemimpin tidak ada kepemimpinan. Pemimpin dapat berupa seorang individu atau dalam kepemimpinan kolektif pemimpin berupa kelompok individu.

Selanjutnya Keating (1986 : 9) dalam makna yang lebih jelas menyatakan bahwa "Kepemimpinan adalah suatu proses dengan berbagai cara mempengaruhi orang atau kelompok orang untuk individu". Selanjutnya Keating menambahkan dari definisinya itu "Kepemimpinan adalah suatu proses dengan berbagai cara mempengaruhi orang atau kelompok orang untuk mencapai suatu tujuan bersama". Senada dengan Keating, Terry (dalam Thoha, 1990 : 5) memiliki 
pemikiran yang sama dengan Keating, hanya saja menggantikan istilah proses dengan kata aktivitas yang pada prinsipnya memiliki padanan kata yang sama. Menurutnya "Kepemimpinan itu adalah aktivitas untuk mempengaruhi orangorang supaya diarahkan mencapai tujuan organisasi".

Hersey dan Blanchard (1982 : 99) mengembangkan definsi kepemimpinan dari sebelumnya, yaitu "Kepemimpinan adalah proses mempengaruhi aktivitas seseorang atau sekelompok orang untuk mencapai tujuan dalam situasi tertentu". Pendapat lain seperti Stogdill (1974 : 459) mencoba mempetakan definisi kepemimpinan secara lebih luas lagi. Dimana dalam pemetaannya itu Stogdill membaginya ke dalam sebelas makna kepemimpinan, sebagai berikut:

(1) Kepemimpinan sebagai proses kelompok; (2) Kepemimpinan sebagai kepribadian yang berakibat; (3) Kepemimpinan sebagai seni menciptakan kesepakatan; (4) Kepemimpinan sebagai kemampuan mempengaruhi; (5) Kepemimpinan sebagai tindakan prilaku; (6) Kepemimpinan sebagai bentuk bujukan; (7) Kepemimpinan sebagai suatu hubungan kekuasaan; (8) Kepemimpinan sebagai sarana pencapaian tujuan; (9) Kepemimpinan sebagai hasil interaksi; (10) Kepemimpinan sebagai pemisah peranan; dan (11) Kepemimpinan sebagai awal struktur.

Sementara itu, pengertian kepemimpinan yang penekanan pemaknaannya kepada nilai-nilai perasaan seperti emosional dan rasional, dikemukakan oleh Rasyid (2002 : 99) bahwa "Kepemimpinan adalah sebuah konsep yang merangkum berbagai segi dari interaksi pengaruh antara pemimpin dengan pengikut dalam mengejar tujuan bersama". Selanjutnya dijelaskan antara pemimpin dan para pengikut terjalin ikatan emosional dan rasional menyangkut kesamaan nilai yang ingin disebar dan ditanam serta kesamaan tujuan yang ingin dicapai. Walaupun dalam kenyataan, sang pemimpinlah yang biasanya memperkenalkan atau bahkan merumuskan nilai dan tujuan.

Dari berbagai pendapat di atas, dapat disimpulkan bahwa pengertian kepemimpinan adalah kemampuan seorang pemimpin dalam menggerakkan dan mempengaruhi pengikutnya untuk mencapai tujuan yang telah ditentukan. Dengan demikian kemampuan seseorang merupakan sifat yang melekat yang ada pada diri orang tersebut. Sedangkan pemimpin adalah individu manusianya. Jadi pemimpin adalah individu manusianya, sedangkan kepemimpinan adalah sifat yang melekat kepadanya sebagai pemimpin. Dari pengertian kepemimpinan tersebut paling tidak ada lima unsur dasar dalam kepemimpinan, yaitu:

1. Unsur pemimpin;

2. Unsur yang dipimpin yaitu pengikut atau kelompok yang dipengaruhi;

3. Adanya proses, yaitu kegiatan mempenggerakkan dan mempengaruhi;

4. Unsur mempengaruhi, adanya interaksi antara pemimpin dan yang dipimpin;

5. Unsur tujuan yang telah ditentukan. 
Salah satu unsur dasar dari kepemimpinan adalah "adanya proses". Proses disini menunjukkan aktivitas seorang pemimpin dalam melaksanakan kegiatan mempengaruhi sikap atau prilaku orang lain. Ketika seorang pemimpin melaksanakan proses untuk mempengaruhi orang lain, maka dari proses tersebut melahirkan tipe kepemimpinan.

Tipe kepemimpinan menurut Nawawi (2003 : 116) adalah “bentuk atau pola atau jenis kepemimpinan yang di dalamnya diimplementasikan satu atau lebih perilaku atau gaya kepemimpinan sebagai pendukungnya". Dari definisi ini terlihat bahwa Tipe kepemimpinan menunjukkan bagaimana aktivitas seorang pemimpin dalam melaksanakan tugas kepemimpinannya. Dari tipe kepemimpinan akan melahirkan perilaku tertentu yang disebut gaya. Jadi gaya merupakan turunan dari kepemimpinan.

Setiap seorang pemimpin didalam melaksanakan kepemimpinannya itu, akan memiliki tipe-tipe yang berbeda satu sama lain. Jadi tipe kepemimpinan itu jumlahnya cukup banyak. Sebagaimana dikemukakan oleh Bogardus (dalam Mar'at, 1984 : 27), mengajukan empat tipe kepemimpinan, yaitu:

1. Tipe otokratik, yang berkuasa di dalam organisasi yang kuat;

2. Tipe demokratik, yang melambangkan interes dari kelompok;

3. Tipe eksekutif, yang memperoleh kepemimpinannya karena segala hal dapat terlaksana;

4. Tipe cerminan intelektual, yang mendapat kesukaran dalam merebut banyak pengikut.

Begitu juga Bell dan Wright (dalam Mar'at, 1984 : 30) ketika melakukan penelitian tentang kepemimpinan masyarakat, keduanya berhasil mengidentifikasikan 4 (empat) tipe kepemimpinan namun dalam konteks pemahaman yang berbeda dengan Bogardus, yaitu:

1. Pemimpin formal, yang memperoleh jabatannya melalui sistem pengangkatan atau pemilihan;

2. Pemimpin reputasional, yang cukup disegani dalam masalah komunitas atau nasional;

3. Pemimpin sosial, berpartisipasi secara aktif dalam organisasi sukarela;

4. Pemimpin berpengaruh yang mempengaruhi orang lain dalam kontak seharihari.

Selain itu, Rivai (2003 : 53-54) mengemukakan tipe kepemimpinan yang lebih sederhana dibandingkan Bogardus. Ada tiga tipe kepemimpinan menurutnya, yakni: (1) otoriter; (2) kepemimpinan bebas dan (3) demokratis. Kartono (2003 : 69) dengan cara merangkum dari pendapat beberapa para ahli, melahirkan delapan tipe kepemimpinan, yakni: (1) tipe karismatik; (2) tipe partenalistik; (3) tipe militeristik; (4) tipe otokrasi/otoritik (authoritative, dominaator); (5) tipe laisser faire; (6) tipe popustis; (7) tipe administratif; dan (8) tipe demokratis. 
Dalam perkembangan lebih lanjut, dari pemahaman tipe-tipe kepemimpinan yang dikemukakan oleh para ahli, Stogdill (1974 : 27) dan Thoha (1990 : 52) cenderung mengerucutkan tipe kepemimpinan menjadi dua tipe utama yaitu authoritative/otokratik dan demokratik.

\section{Gaya Kepemimpinan Sebagai Pendekatan Komunikasi}

Dalam memahami gaya kepemimpinan sebagai pendekatan komunikasi, maka secara nyata dapat di lihat melalui fungsi-fungsi kepemimpinan sebagaimana diuraikan Siagian (1989 : 22-23), sebagai berikut:

1. Penentu arah yang hendak ditempuh oleh organisasi dalam usaha mencapai tujuan dan berbagai sasaran;

2. Wakil dan juru organisasi terutama dengan mereka yang tergolong sebagai "stakeholder";

3. Komunikator yang efektif;

4. Mediator yang handal, khususnya dalam mengatasi berbagai situasi konflik yang mungkin timbul antara individu dalam suatu kelompok kerja yang terdapat dalam organisasi yang dipimpinnya;

5. Integrator yang rasional dan objektif.

Bahkan secara lebih luas lagi fungsi-fungsi kepemimpinan seperti yang diuraikan Wirawan (2002 : 95-115), dimana yang bersangkutan mengemukakan 8 (delapan) fungsi kepemimpinan, sebagai berikut:

1. Menciptakan visi;

2. Mengembangkan budaya organisasi;

3. Menciptakan sinergi;

4. Memberdayakan pengikut/staf;

5. Menciptakan perubahan;

6. Memotivasi pengikut;

7. Mewakili sistem sosialnya;

8. Membelajarkan organisasi.

Apa yang dikemukakan tentang fungsi kepemimpinan di atas, pada prinsipnya cukup beragam. Karena itu, keberhasilan seorang pemimpin dalam melaksanakan fungsinya tersebut sangat dipengaruhi oleh gaya seseorang di dalam memimpin. Gaya yang tepat dan diterima oleh masyarakat, hal ini sangat membantu seorang pemimpin dalam menggerakkan partisipasi masyarakat yang dipimpinnya. Keberhasilan menggerakkan partisipasi masyarakat dalam pemerintahan akan memudahkan seorang pemimpin mewujudkan tugas pemerintahan dan pembangunan.

Gaya kepemimpinan sebagaimana dikemukakan Thoha (1990 : 51-52) merupakan "norma perilaku yang digunakan oleh seseorang pada saat orang tersebut mencoba mempengaruhi perilaku orang lain seperti yang ia lihat. Dalam hal ini usaha menselaraskan persepsi diantara orang yang akan mempengaruhi 
perilaku dengan orang yang perilakunya akan dipengaruhi menjadi amat penting kedudukannya".

Pengertian gaya kepemimpinan yang hampir sama, dikemukakan oleh Hersey dan Blanchaard (dalam Nawawi, 2003 : 115) mengatakan: "Gaya kepemimpinan adalah pola perilaku pada saat seseorang mencoba mempengaruhi orang lain dan mereka menerimanya". Sementara Agus Dharma (1994: 87) mengungkapkan "Gaya kepemimpinan adalah pola tingkah laku yang dipertunjukkan seseorang pada saat ia mencoba mempengaruhi orang lain".

Berdasarkan pendapat di atas, pengertian gaya kepemimpinan pada dasarnya adalah cara yang dipergunakan seorang pemimpin di dalam mempengaruhi orang lain, sehingga mereka mau mengikutinya. Melalui gaya kepemimpinan dimaksud pada dasarnya berorientasi pada dua pola yaitu:

1. Pola hubungan yaitu, seberapa sering seorang pimpinan berkomunikasi dengan bawahan sesuai dengan tingkat kematangannya.

2. Pola tugas yaitu, sejauh berapa banyak seorang pimpinana memberikan tugastugas kepada bawahan sesuai dengan tingkat kemampuannya.

\section{Partisipasi Masyarakat}

\section{Pengertian Partisipasi}

Banyak definisi partisipasi mulai dari yang sederhana sampai kepada yang lebih kompleks. Definisi yang sederhana sebagaimana dikemukakan Hasim dan Remiswai (2009 : 23) bahwa partisipasi umumnya bermakna mengajak masyarakat untuk turut bekerja atau melaksanakan suatu kegiatan yang ditujukan untuk kepentingan masyarakat. Apa yang dikemukakan tersebut menandakan bahwa partisipasi sebagai bentuk ajakan kepada masyarakat untuk mau melaksanakan kegiatan yang manfaatkan kembali kepada masyarakat itu sendiri. Jadi makna partisipasi disini hanya sebatas keikutsertaan masyarakat.

Canter (dalam Arimbi, 1993 : 1) mendefinisikan partisipasi sebagai feedforward information and feedback information. Definisi ini memperlihatkan bahwa partisipasi masyarakat sebagai proses komunikasi dua arah yang terus menerus dilakukan. Proses komunikasi disini merupakan komunikasi antara pihak pemerintah sebagai pemegang kebijakan dan masyarakat sebagai pihak yang merasakan langsung dampak dari kebijakan tersebut. Pendapat Canter tersebut, tersirat juga bahwa masyarakat dapat memberikan respon positif dalam arti mendukung atau memberikan masukan terhadap program atau kebijakan yang diambil oleh pemerintah namun dapat juga menolak kebijakan tersebut.

Sementara itu, Cary (dalam Hasim dan Remiswai, 2009 : 23) menyatakan partisipasi masyarakat adalah adanya kebersamaan atau saling memberikan sumbangan untuk kepentingan dan masalah-masalah bersama yang tumbuh dari kepentingan dan partisipasi individu warga masyarakat itu sendiri. Apa yang 
dikemukakan Cary partisipasi merupakan hasil consensus social warga masyarakat akan arah perubahan sosial yang diharapkan masyarakat.

Mubyarto (1984 : 35) mendefinisikan partisipasi sebagai kesediaan untuk membantu keberhasilan setiap program sesuai dengan kemampuan setiap orang tanpa berarti mengorbankan kepentingan diri sendiri. Mubyarto mengungkapkan bahwa sesuatu itu baru dikatakan partisipasi apabila masyarakat berupaya mensukseskan suatu kebijakan atau program yang dilaksanakan oleh pemerintah. Keterlibatan masyarakat di dalam kegiatan tersebut tidak mesti mengorbankan kepentingan atau kebutuhan pribadi mereka.

Sedangkan Cohen (dalam Hasim dan Remiswai, 2009 : 24) mendefinisikana partisipasi ke dalam empat hal, yaitu: “...... participation in decision making, participation in implementation, participation in benefits, and participation in evaluation". Definisi lain dikemukakan oleh Nelson, Bryant dan White (1982 : 206) menyebutkan dua macam partisipasi :

Partisipasi antara sesama warga atau anggota suatu perkumpulan yang dinamakannya partisipasi horizontal, dan partisipasi yang dilakukan oleh bawahan dengan atasan antara klien dengan patron, atau antara masyarakat sebagai suatu keseluruhan dengan pemerintah, yang diberi nama partisipasi vertikal. Keterlibatan dalam berbagai kegiatan politik seperti pemberian suara dalam pemilihan, kampanye, dan sebagainya, disebut partisipasi dalam proses politik, sedangkan keterlibatan dalam kegiatan seperti perencanaan dan pelaksanaan pembangunan disebut partisipasi dalam proses administrasi.

Keterlibatan kelompok atau masyarakat sebagai suatu kesatuan, dapat disebut partisipasi kolektif, sedangkan keterlibatan individu dalam kegiatan kelompok dapat disebut partisipasi individual. Partisipasi yang dimaksud ialah partisipasi vertical dan horizontal masyarakat. Disebut partisipasi vertical karena bisa terjadi dalam kondisi tertentu masyarakat terlibat atau mengambil bagian dalam suatu program pihak lain, dalam hubungan mana masyarakat berada pada posisi sebagai bawahan, pengikut atau klien. Disebut partisipasi horizontal, karena pada suatu saat tidak mustahil masyarakat mempunyai kemampuan untuk berprakarsa, dimana setiap anggota/kelompok masyarakat berpartisipasi horizontal satu dengan yang lain, baik dalam melakukan usaha bersama, maupun dalam rangka melakukkan kegiatan dengan pihak lain. Tentu saja partisipasi seperti ini merupakan suatu tanda permulaan tumbuhnya masyarakat yang mampu berkembang secara mandiri.

Oakley (1991: 9) memberikan pemahaman yang lebih luas tentang konsep partisipasi, dengan mengelompokkan ke dalam tiga pengertian pokok, yaitu:

1. Partisipasi sebagai kontribusi, partisipasi diartikan sebagai sumbangsih sukarela atau bentuk-bentuk sumbangsih lain dari masyarakat terhadap suatu proyek yang sudah ditentukan pemerintah; 
2. Partisipasi sebagai organsisasi, menyangkut bagaimana mengembangkan organisasi yang diperlukan sebagai mesin penggerak partisipasi;

3. Partisipasi sebagai pemberdayaan; partisipasi haruslah melibatkan pemberdayaan masyarakat, dalam arti bahwa transfer kekuasaan merupakan unsur yang tersirat dalam partisipasi.

Sementara itu, Tjokroamidjojo (1987 : 24) memberikan pengertian tentang partisipasi dan hubungannya dengan proses pembangunan di bidang ekonomi, yaitu:

Keterlibatan dalam penentu arah, strategi dan kebijakan pembangunan yang dilakukan pemerintah; keterlibatan dalam memikul beban dan tanggungjawab dalam melaksanakan kegiatan pembangunan; dan keterlibatan dalam memetik hasil dan manfaat pembangunan secara berkeadilan. Ia juga mengemukakan ada dua cara partisipasi yaitu mobilisasi kegiatan-kegiatan masyarakat yang serasi untuk kepentingan pencapaian tujuan pembangunan; dan peningkatan swadaya dan swakarya dari masyarakat itu sendiri, terutama ditujukan kepada sector swasta terutama ditujukan kepada sector swasta melalui mekanisme pasar.

Kaitannya partisipasi dalam program pembangunan, Oakley (dalam Hasim dan Remiswai, 2009 : 25) menginterprestasikan partisipasi terutama dalam pembangunan ke dalam empat pernyataan yaitu:

1) Partisipasi dianggap sebagai suatu sumbangan sukarela dari seseorang kepada orang lain atau kepada program-program publik yang diperkirakan akan memberikan suatu sumbangan kepada pembangunan nasional. Akan tetapi orang tersebut tidak mengharapkan untuk ambil bagian dalam membentuk program ataupun mengkritik isi program tersebut;

2) Partisipasi berkaitan dengan pembangunan desa. Partitipasi adalah keterlibatan masyarakat dalam proses pembuatan keputusan serta pelaksanaan program bersama-sama mendapatkan keuntungan dari program pembangunan dan keterlibatan dalam upaya-upaya untuk menilai program-program pembangunan;

3) Partisipasi berkaitan dengan usaha-usaha yang terorganisasi untuk meningkatkan pengawasan sumber-sumber dan lembaga-lembaga pemerintah;

4) Partisipasi masyarakat adalah proses aktif dari kelompok tertentu yang diuntungkan atau pun kelompok kelayakan tertentu yang mempengaruhi arah dan pelaksanaan program pembangunan dengan asumsi untuk meningkatkan taraf kesejahteraan yang berkaitan dengan pendapatan, pertumbuhan personal, swadaya atau nilai-nilai lainnya yang berkaitan dengan harapan masyarakat. 
Dalam pengembangan partisipasi, diperlukan adanya partisipasi dari masyarakat. Menurut Soetrisno (1995: 221) secara umum ada dua jenis partisipasi yang beredar di masyarakat, yaitu:

1) Partisipasi rakyat dalam pembangunan sebagai dukungan rakyat terhdap rencana/proyek pembangunan yang dirancang dan ditentukan tujuannya oleh perencana. Ukuran tinggi rendahnya partisipasi rakyat dalam definisi ini pun diukur dengan kemampuan rakyat ikut menanggung biaya pembangunan, baik berupa uang maupun tenaga dalam melaksanakan proyek pembangunan pemerintah;

2) Partisipasi masyarakat dalam pembangunan merupakan kerjasama yang erat antara perencana dan rakyat dalam merencanakan, melaksanakan, melestarikan danmengembangkan hasil pembangunan yang telah dicapai. Ukuran tidak hanya diukur dengan kemauan rakyat untuk menanggung biaya pembangunan, tetapi juga dengan ada tidaknya hak rakyat untuk ikut menentukan arah dan tujuan proyek yang akan dibangun di wilayah mereka. Ukuran lain yang dapat digunakan adalah ada tidaknya kemauan rakyat untuk secara mandiri melestarikan dan mengembangkan hasil proyek itu.

Partisipasi masyarakat tampak menjadi elemen penting dalam pengembangan masyarakat. Menurut Adi (2003 : 298) keterlibatan masyarakat tidak saja dilihat pada tahap perencanaan dan pelaksanaan saja tetapi sudah meluas hingga tahap assessment dan evaluasi. Tahap yang dimaksud Adi meliputi (1) Tahap assessment; (2) Tahap perencanaan alternatif program atau kegiatan; (3) Tahap pelaksanaan (implementasi) program atau kegiatan; dan (4) Tahap evaluasi (termasuk didalamnya evaluasi input, proses dan hasil). Lebih jauh dijelaskan bahwa dengan pendekatan consensus dari pengembangan masyarakat, proses pemberdayaan yang dilakukan dalam upaya membuat masyarakat menjadi lebih pandai terutama kaitannya dengan penanganan masalah-masalah yang muncul di masyarakat.

Apabila dilihat dari kerangka dasarnya, secara sederhana tergambar bahwa mekanisme pembangunan di Indonesia merupakan suatu proses perpaduan antara (1) kelompok kegiatan utama, yaitu berbagai kegiatan pemerintah di satu pihak dan (2) kegiatan partisipasi masyarakat di lain pihak. Kegiatan pemerintah dilakukan melalui program-program sektoral dari berbagai departemen dan lembaga non departemen. Pemerintah sesuai dengan peraturan perundangan yang berlaku berkewajiban untuk memberikan bimbingan, pengarahan, pembinaan dan bantuan dalam batas-batas kemampuan yang tersedia, disertai pengawasan yang intensif. Disisi lain kegiatan partisipasi masyarakat tidak jarang banyak didukung ataupun digerakkan oleh organisasi non pemerintah, yang pada titik tertentu sangat memerlukan dukungan dari pemerintah dalam pelaksanaan tugasnya. 
Oakley (199:1-10) mengatakan bahwa masyarakat dapat melakukan partisipasi melalui beberapa indikator, yaitu:
a. Sumbangan pikiran (ide atau gagasan);
b. Sumbangan materi (dana, barang, alat);
c. Sumbangan tenaga (bekerja atau memberi kerja);
d. Memanfaatkan dan melaksanakan pelayanan pembangunan;
e. Partisipasi sebagai pemberdayaan, partisipasi merupakan latihan pemberdayaan bagimasyarakat desa, meskipun sulit untuk didefinisikan akan tetapi pemberdayaan merupakan upaya untuk mengembangkan keterampilan dan kemampuan masyarakat desa untuk memutuskan dan ikut terlibat dalam pembangunan.

Dengan demikian, partisipasi adalah suatu keadaan dimana seseorang ikut merasakan bersama-sama dengan orang lain sebagai akibat dari terjadinya interaksi sosial, hal ini merupakan kesadaran yang dimotivasi oleh kebutuhan untuk berkelompok atas dasar kesenangan atau sesuatu yang dirasakan berguna atas dasar persahabatan dan saling simpati. Jadi turutnya orang lain bergabung karena dirasakan ada keuntungan yang diperolehnya, merupakan suatu bentuk partisipasi. Keuntungan disini bisa berupa materi maupun sosial (kepuasan, kebahagiaan, kegembiraan, dsb). Partisipasi diartikan sebagai suatu proses kegiatan bersama termasuk didalamnya keikutsertaan setiap individu dalam suatu kelompok tentang tanggungjawab dan konsekuensi dari tugas-tugas yang bersifat umum sampai kepada tugas yang bersifat khusus. Partisipasi dapat dibagi dua yaitu bersifat umum dan bersifat khusus yang dikaitkan dengan aspek-aspek yang lebih khusus seperti bidang politik, ekonomi, sosial budaya, sehingga melahirkan partisipasi ekonomi atau partisipasi sosial. Dalam proses pembangunan, dilihat dari pihak yang terlibat, terdapat tiga komponen penting yaitu lembaga atau agen pembaharu (Pemerintah atau non pemerintah), dan kelompok target/sasaran (kelompok masyarakat). Setiap komponen harus mengembangkan kesadaran akan pentingnya partisipasi dalam proses pembangunan, kemudian menumbuhkembangkan komitmen untuk mau bekerjasama dalam setiap tahap pembangunan.

\section{Bentuk Partisipasi}

Berbicara mengenai bentuk partisipasi masyarakat, maka partisipasi dapat bersifat individu atau kolektif, terorganisir atau tidak terorganisir dan yang terjadi secara spontan dan sukarela. Berkaitan dengan bentuk partisipasi, hal ini dapat dilihat dari pendapat Bryant dan White dalam Ndraha (1987 : 102) yang menyebutkan ada dua macam bentuk partisipasi, yaitu: Partisipasi antara sesama warga atau anggota suatu perkumpulan yang dinamakan partisipasi horizontal dan partisipasi yang dilakukan bawahan dengan atasan, atau antara klien dengan 
patron atau antara masyarakat sebagai suatu keseluruhan dengan pemerintah yang diberi nama partisipasi vertikal. Pendapat Bryant dan White ini dapat dipahami bahwa partisipasi tersebut dapat terjadi dengan pola top-down yakni pihak yang memegang kebijakan melakukan instruksi kepada pihak bawahannya sehingga kebijakan tersebut dapat dilakukan. Namun partisipasi juga dapat terjadi pada posisi masing-masing pihak berada dalam level atau garis yang sama.

Untuk dapat melihat bentuk partisipasi masyarakat, dapat dicermati pendapat dari Cormic (dalam Arimbi, 1993 : 2) yang membedakan partisipasi masyarakat dalam proses pengambilan keputusan berdasarkan sifatnya yaitu, bersifat konsultatif dan bersifat kemitraan. Partisipasi konsultatif terjadi antara pihak pejabat pengambil keputusan dengan kelompok masyarakat yang berkepentingan. Anggota masyarakat mempunyai hak untuk didengar pendapatnya dan untuk diberi tahu, namun keputusan akhir tetap berada ditangan pembuat keputusan. Sementara partisipasi masyarakat yang bersifat kemitraan, pejabat pembuat keputusan dan anggota-anggota masyarakat merupakan mitra yang relatif sejajar kedudukannya. Mereka bersama-sama membahas masalah, mencari alternatif pemecahan masalah dan membuat keputusan.

Pendapat Cormic apabila dibandingkan dengan pendapat Bryant dan White (dalam Arimbi, 1993 : 2) ada persamaannya yakni, partisipasi terjadi secara top-down dalam arti pemerintah dapat mengkonsultasikan kebijakan tersebut kepada masyarakat. Dalam istilah Bryant dan White disebut dengan partisipasi vertical. Sementara Cormic menamakannya dengan partisipasi konsultatif. Partisipasi horizontal menurut Bryant dan White sedikit berbeda dengan pola kemitraan menurut Cormic. Partisipasi horizontal yang terjadi kesepakatan kelompok atau individu yang selevel sementara kemitraan ada dialog dan kesepakatan antara pemegang kebijakan dengan masyarakat.

Dari sisi bentuk partisipasi, juga dijelaskan oleh Wenger (dalam Arimbi, 1993 : 3) yang melibatkan partisipasi masyarakat dengan merinci, sebagai berikut:

1. Partisipasi masyarakat sebagai suatu kebijakan.

Pengaruh paham ini berpendapat bahwa partisipasi masyarakat merupakan suatu kebijakan yang tepat dan baik untuk dilaksanakan;

2. Partisipasi masyarakat sebagai strategi.

Partisipasi masyarakat ini mendalikan bahwa partisipasi masyarakat merupakan strategi untuk mendapatkan dukungan (publicsupport);

3. Partisipasi masyarakat sebagai alat komunikasi.

Partisipasi masyarakat sebagai alat komunikasi didayagunakan sebagai alat untuk mendapatkan masukan berupa informasi dalam proses pengambilan keputusan;

4. Partisipasi masyarakat sebagai alat penyelesaian sengketa. 
Dalam konteks ini partisipasi masyarakat didayagunakan sebagai suatu cara untuk mengurangi atau meredakan konflik melalui usaha pencapaian concensur dari pendapat-pendapat yang ada.

5. Partisipasi masyarakat sebagai terapi.

Menurut persepsi ini, peran masyarakat dilakukan sebagai upaya mengobati masalah-masalah psikologis masyarakat seperti halnya perasaan ketidakberdayaan, tidak percaya diri dan perasaan bahwa diri mereka bukan sebagai komponen yang penting dalam masyarakatnya.

Siagian (1985 : 32) menyatakan bahwa partisipasi masyarakat dapat berbentuk partisipasi pasif dan aktif. Partisipasi pasif dapat berarti bahwa dalam sikap, perilaku dan tindakannya, rakyat melakukan hal-hal yang dapat menghalangi lancarnya proses pembangunan. Partisipasi aktif dapat terwujud dalam berbagai bentuk:

1. Turut memikirkan nasib sendiri dengan memanfaatkan lembagalembaga sosial dan politik yang ada di tengah-tengah masyarakat sebagai saluran aspirasinya;

2. Menunjukkan adanya kesadaran bermasyarakat dan bernegara yang tinggi dengan tidak menyerahkan penentuan nasibnya kepada orang lain, seperti kepada pemimpin dan tokoh masyarakat yang ada, baik yang bersifat formal maupun informal;

3. Memenuhi kewajiban sebagai warga Negara yang bertanggung jawab seperti membayar pajak secara jujur serta kewajiban lainnya;

4. Mentaati berbagai peraturan perundang-undangan yang berlaku, kerelaan melakukan pengorbanan yang dituntut oleh pembangunan demi kepentingan bersama yang lebih luas dan lebih penting.

Sejalan dengan berbagai makna partisipasi di atas, Kramer sebagaimana dikutip oleh Soetomo (1995 : 134-135) mengatakan ada 4 bentuk partisipasi, yaitu:

1. Partisipasi dalam pengambilan keputusan, bahwa dengan terlibat dalam proses pengambilan keputusan, diharapkan kepentingan dan permasalahan akan dapat tercermin dalam program yang dibuat;

2. Partisipasi dalam perkembangan program, bahwa masyarakat sebagai kelompok sasaran merupakan konsumen program, maka perlu didengar pendapat dan sarannya terutama tentang kebutuhan dan kepentingan serta aspirasi nyata;

3. Partisipasi yang menekankan pada keterlibatan dalam gerakan social, dimana masyarakat sebagai pihak yang powerless dapat menjadi pressure group yang efektif; 
4. Partisipasi berupa keterlibatan dalam berbagai pekerjaan, bahwa masyarakat yang tidak memiliki altenatif lain dalam pekerjaannya, maka dapat bekerja guna memperoleh pendapat melalui program tersebut.

\section{Tujuan dan Manfaat Partisipasi}

Tujuan dasar dari partisipasi masyarakat adalah untuk menghasilkan masukan dan persepsi yang berguna dari warga masyarakat yang berkepentingan (public interest) dalam rangka meningkatkan kualitas pengambilan keputusan (Arimbi, 1994 : 8). Dengan keterlibatan masyarakat yang potensial terkena dampak kegiatan dan kelompok kepentingan (interest group), para pengambil keputusan dapat menangkap pandangan, kebutuhan, pengharapan dari masyarakat dan kelompok tersebut serta menuangkannya ke dalam konsep.

Berkaitan dengan tujuan partisipasi masyarakat, Ndraha (1990 : 67) mengemukakan bahwa tujuan partisipasi masyarakat dalam pembangunan adalah:

a. Mengusahakan, memelihara, atau merawat segenap sumber, asset dan sarana prasarana baik yang berupa fisik maupun yang non fisik;

b. Membangkitkana kembali semangat masyarakat dari keadaan jatuh atua mundur sebagai akibat dari kekeliruan yang pernah ditempuh;

c. Masyarakat dapat memberikan respon yang positif terhadap setiap perubahan social yang tengah berlangsung;

d. Masyarakat dapat mengembangkan serta meningkatkan sumber, asset atau peralatan yang ada dalam proses pembangunan.

Partisipasi masyarakat dapat berjalan apabila didukung oleh kondisi dan situasi baik dari sisi intern masyarakat itu sendiri ataupun faktor lain yang mempengaruhinya. Mengenai lemahnya partisipasi, menurut Prabatmojo (2001 : 49) mengatakan bahwa kendala yang dihadapi dalam penyelenggaraan partisipasi masyakat, yaitu:

a. Pemimpin yang tidak mempunyai pengaruh dan pasif dalam mengambil inisiatif untuk memulai kegiatan partisipasi;

b. Sebagian masyarakat yang mengharapkan insentif;

c. Apabila tidak ada kesepakatan masyarakat terhadap kebutuhan dalam cara mewujudkan kebutuhan tersebut;

d. Terdapat sebagian masyarakat yang tidak mau mengorbankan sebagian miliknya untuk kepentingan bersama;

e. Apabila kegiatan tersebut tidak langsung mempengaruhi kebutuhan mendasar anggota masyarakat. 
Bagaimanapun juga partisipasi masyarakat dalam setiap kegiatan atau program yang dijalankan tentunya ada situasi yang mempengaruhinya baik dari sisi positif maupun negatif. Berhasil atau tidaknya partisipasi masyarakat akan dipengaruhi berbagai faktor, baik faktor dari dalam (internal) maupun dari luar (eksternal). Faktor-faktor yang mempengaruhi partisipasi masyarakat, menurut Darjono (dalam Sastropoetra, 1988 : 22) terdiri dari:

a. Pendidikan, kemampuan membaca dan menulis, kemiskinan, kedudukan social dan percaya terhadap diri sendiri;

b. Faktor lain penginterprestasian yang dangkal terhadap agama;

c. Kecenderungan untuk menyalah artikan motivasi, tujuan dan kepentingan organisasi penduduk yang biasanya mengarah kepada kepentingan organisasi penduduk yang biasanya mengarah kepada timbulnya persepsi yang salah terhadap keinginan dan motivasi serta organisasi penduduk seperti halnya terjadi di beberapa Negara;

d. Tersedianya kesempatan kerja yang lebih baik;

e. Tidak terdapatnya kesempatan untuk berpartisipasi dalam berbagai program pembangunan.

Pendapat di atas terungkap bahwa pendidikan menempati pengaruh penting dalam partisipasi masyarakat. Partisipasi masyarakat juga didorong oleh adanya motivasi yang kuat serta adanya kesempatan untuk terlibat dalam suatu kegiatan yang sedang dilaksanakan. Sebagai bahan perbandingan ada baiknya mencermati pendapat Tjokroamodjojo (1985 : 45-47) mengenai faktor-faktor yang mempengaruhi partisipasi masyarakat. Tjokroamidjojo menyatakan faktor-faktor yang perlu mendapatkan perhatian dalam partisipasi masyarakat adalah:

1. Faktor kepemimpinan, dalam menggerakkan partisipasi masyarakat sangat dituntut pimpinan yang berkualitas;

2. Faktor komunikasi, gagasan-gagasan, ide, kebijaksanaan dan rencanarencana baru akan mendapat dukungan masyarakat apabila diketahui dan dimengerti oleh masyarakat;

3. Faktor pendidikan, dengan tingkat pendidikan yang memadai, masyarakat individu akan dapat memberikan partisipasi sesuai dengan apa yang diharapkan.

Pendapat Tjokroamidjojo itu dapat dipahami bahwa dalam partisipasi juga dituntut adanya hubungan yang harmonis antara pihak yang mengeluarkan kebijakan dan masyarakat sebagai pihak yang merasakan langsung dampak dari kebijakan yang diambil tersebut. Hubungan ini memerlukan pemimpin yang mengerti kondisi masyarakat. Pemimpin yang berkualitas dengan pendidikan yang baik dan didukung oleh seluruh masyarakat akan menciptakan kondisi dan situasi yang kondusif dalam perjalanan partisipasi masyarakat. 
Hal lainnya mengenai faktor-faktor yang mempengaruhi partisipasi masyarakta juga diuraikan oleh Ife (1995 : 113) yang melihat kondisi yang mempengaruhi partisipasi antara lain:

1. Masyarakat akan berpartisipasi jika mereka merasa masalah atau kegiatan itu penting baginya;

2. Masyarakat akan berpartisipasi jika akan menimbulkan suatu perubahan dan adanya nilai tambah baginya;

3. Adanya perbedaan bentuk dari partisipasi masyarakat diakui sesuai dengan nilai-nilai yang mereka miliki;

4. Masyarakat yang mungkin berpartisipasi jika mereka mendapatkan dukungan atau dorongan;

5. Masyarakat akan berpartisipasi jika diciptakan suatu proses yang memungkinkan terjadinya partisipasi.

Uraian Ife itu memiliki persamaan dengan pendapat Tjokroamidjojo yakni masyarakat akan berpartisipasi apabila mereka mengerti dan memahami partisipasi yang mereka lakukan, masyarakat juga hendaknya memilik waktu yang cukup untuk terlibat didalamnya. Namun Ife menambahkan kegiatan yang sedang berlangsung tidak bertentangan dengan nilai yang dianut masyarakat.

Untuk lebih memberikan pemahaman terhadap faktor yang mempengaruhi partisipasi akan diberikan perbandingan dengan apa yang diungkapkan oleh Conyers (1991 : 186). Conyers melihat ada beberapa faktor yang mendorong terjadinya partisipasi, yaitu:

1. Hasil keterlibatannya itu sendiri, dalam arti masyarakat akan berpartisipasi atas kemauan sendiri atau antusias yang tinggi kalau mereka merasa bahwa partisipasi mereka mempunyai pengaruh pada rencana akhir;

2. Apa yang direncanakan masyarakat tersebut akhirnya menjadi keputusan akhir tidak seperti yang umumnya terjadi, dimana masyarakat dilibatkan dalam perencanaan namun pada hasil akhir keputusan yang diambil oleh seseorang atau kelompok tertentu dan tidak mencerminkan apa yang telah direncanakan masyarakat;

3. Masyarakat akan berpartisipasi dalam kegiatan-kegiatan yang menarik minat mereka atau aktivitas yang mempunyai pengaruh langsung dan dapat mereka rasakan;

4. Dalam upaya menggalang partisipasi suatu komunitas, perencana harus mampu menyesuaikan diri mengenai apa yang penting dan yang tidak penting oleh komunitas tersebut, bukannya apa yang harus melibatkan masyarakat setempat. 
Partisipasi akan berjalan apabila masyarakat merasakan partisipasi yang mereka berikan membawa dampak positif sehingga kontribusi dari partitipasi tersebut berpengaruh langsung bagi kehidupan yang mereka jalani. Proses pembangunan yang disepakati dengan sikap apatis akan menjadi penghalang dalam upaya menumbuhkan partisipasi masyarakat. Sikap apatis masyarakat seperti itu disebabkan oleh beberapa faktor sebagaimana diungkap Raharjo (1983 : 15), yakni:

1. Sikap orang acuh tak acuh dalam pembangunan karena kurang memahami mengenai suatu permasalahan atau tujuan kegiatan yang membutuhkan partisipasi mereka;

2. Orang tidak yakin bahwa untuk mempengaruhi suatu kebijakan dengan partisipasi akan berhasil;

3. Orang yang tidak ikut berpartisipasi karena ia berasal dari suatu lingkungan yang tidak kondusif dan menganggap partisipasi suatu yang kurang terpuji.

Dari konsep pemahaman di atas, terlihat bahwa partisipasi akan efektif apabila masyarakat merasa terlibat dalam suatu kegiatan dan kegiatan tersebut memberikan dampak positif sehingga dinilai bermanfaat bagi kepentingan mereka. Partisipasi akan lebih efektif apabila masyarakat memiliki kesempatan yang cukup untuk terlibat di dalamnya.

Berpijak pada landasan teoritis di atas, dapat disimpulkan bahwa definisi konseptual partisipasi masyarakat adalah bentuk keterlibatan masyarakat dalam kegiatan pembangunan perdesaan yang diperlihatkan dari konstribusi yang diberikan masyarakat dalam kegiatan tersebut sesuai kemampuan. Sedangkan indikator partisipasi masyarakat sebagaimana dikemukakan oleh Oakley (1991 : 110), terdapat 5 (lima) indikator dalam partisipasi masyarakat, yaitu:

1. Sumbangan pikiran (ide atau gagasan);

2. Sumbangan materi (dana, barang, alat);

3. Sumbangan tenaga (bekerja atau memberi kerja);

4. Memanfaatkan dan melaksanakan pelayanan pembangunan;

5. Partisipasi sebagai pemberdayaan, dimana partisipasi merupakan latihan pemberdayaan bagi masyarakat desa. Pemberdayaan merupakan upaya untuk mengembangkan keterampilan dan kemampuan masyarakat desa untuk memutuskan dan ikut terlibat dalam pembangunan.

\section{Penutup}


Berdasarkan uraian sebagaimana yang telah dikemukakan diatas maka selanjutnya berikut ini disampaikan beberapa catatan sebagai kesimpulan sebagai berikut :

1. Peranan komunikasi dalam kepemimpinan pemerintahan merupakan salah satu faktor yang sangat penting di dalam menyampaikan pesanpesan yang jelas, terarah dan terencana di dalam proses dan interaksi kegiatan pemerintahan dan pembangunan sebagai upaya pemantapan dan pemberian pengertian kepada masyarakat tentang program dan kegiatan yang akan dilaksanakan untuk peningkatan kesejateraan masyarakat.

2. Kepemimpinan pemerintahan sebagai penggerak dan komunikator yang baik, akan sangat bermanfaat dalam pengolahan potensi sumber daya alam dan sumber daya manusia yang terwujud dalam kegiatan pelayanan masyarakat, pemberdayaan masyarakat dan peningkatan partisipasi masyarakat serta pemantapan kualitas hidup masyarakat.

3. Gaya kepemimpinan merupakan proses komunikasi dan cara yang dipergunakan seorang pemimpin di dalam mempengaruhi orang lain sehingga meraka mau mengikutinya dan mengambil manfaat dari interaksi perilaku hubungan dan perilaku tugas yang terjadi antara pemimpin dan pengikutnya.

4. Dinamika partisipasi masyarakat dapat tumbuh dan berkembang, merespon kebijakan kepemimpinan pemerintahan melalui interaksi komunikasi antara pemerintah, masyarakat dan dunia usaha dalam mewujudkan kemajuan dan kepentingan bersama.

5. Pendekatan komunikasi yang sederhana dan persuasip akan membangkitkan kesadaran dan spontanitas masyarakat berdasarkan pengertian akan manfaat yang akan diperoleh masyarakat sebagai suatu proses kegiatan dari rakyat, oleh rakyat dan untuk rakyat.

\section{Daftar Pustaka}

Andre Hardjana, 2000. Audit Komunikasi, Teori dan Praktek. Penerbit PT Grasindo.

Avolio, B.J., Wildman, D.A., \& Einsten, Walter, 1998. Transformasional Leadership in a Management Game Simulation. Group \& Organization Studies. Vol. 13.

Berartha, I Nyoman, 1982. Desa, Masyarakat Deas dan Pembangunan Desa. Jakarta: Ghalia Indonesia.

Effendy, Khasan, 2009. Pergeseran Kepemimpinan Desa. Bandung: CV. Indra Prahasta.

Hersey, Paul dan Kenneth Blanchard, 1995. Manajemen Perilaku Organisasi, Pendayagunaan Sumber Daya Manusia, Penerjemah: Agus Dharma. Jakarta: Penerbit Erlangga. 
Hikmat, Harry, 2001. Strategi Pemberdayaan Masyarakat. Bandung: Humaniora Utama Press.

Goldhaber, Gerald M. organizational Communication. Fifth edition. Dubuque, IA: Wm C. Brown Publisher, 1990.

Miftah, Thoha, 1996. Perilaku Organisasi-Konsep Dasar dan Aplikasinya, Jakarta: PT Raja Grafindo.

Mikkelsen, Britha, 1999. Metode Penelitian Partisipasi dan Upaya-upaya Pemberdayaan. Jakarta: Penerbit Yayasan Obor Indonesia.

Nelson, Nici and Wright, Susan, 1982. Power and Participatory Development: Theory and Practice. London: Intermediate Technology Publications.

Oakley, Petter, et, al, 1991. Project with People: The Practice of Participation in Rural Development, Granevallo.

Pamudji, S. 1982. Kepemimpinan Pemerintahan di Indonesia. Jakarta : Bina Aksara.

Pace R. Wayne dan Don F. Faules, 1998. Komunikasi Organisasi. Penerbit PT Remaja Rosdakarya Bandung.

Siagian, Sondang, P. 2002. Kiat Meningkatkan Produktivitas. Jakarta: Penerbit Rineka Cipta.

Suradinata, Ermaya. 1998. Manajemen Pemerintahan dan Otonomi Daerah. Bandung: Ramadan.

Taliziduhu, Ndraha, 1990. Pembangunan Masyarakat, Jakarta: Rineka Cipta. 